\title{
Renin-aldosterone axis in refractory hepatic ascites. Characterization of the response of the axis to both the acute and long term effects of peritoneovenous shunting
}

\author{
P.J. CAMPBell, MD, P.D. GRIEG, MD, L.M. BLENDIS, MD
}

\begin{abstract}
Twenty-two patients with refractory ascites secondary to chronic liver disease undergoing peritoneovenous shunting (PVS) were studied under strict metabolic conditions, preoperatively and for the first $8 \mathrm{~h}$ postoperatively. Fourteen subjects were restudied under similar metabolic conditions three months post-PVS. Thirteen of the 22 patients $(59 \%)$ had an immediate dramatic natriuresis and entered negative sodium balance (group A), the remaining nine patients $(41 \%)$ remained in positive sodium balance during the first $8 \mathrm{~h}$ post-PVS (group B). Group B was characterized preoperatively by significantly higher mean plasma renin activity $(\mathrm{P}<0.01)$ and serum aldosterone levels $(\mathrm{P}<0.01)$ compared to group A. Yet, plasma renin activity and aldosterone levels in both groups were similar at $8 \mathrm{~h}$ following shunting. At three months post-PVS in the 14 patients restudied, mean plasma renin activity and serum aldosterone levels were not significantly elevated above the normal range. Yet the patients still demonstrated continued sodium retention on a $20 \mathrm{mEq}$ sodium diet, mean sodium excretion $10.5 \pm 2.8$ $\mathrm{mEq} /$ day. The close correlation of serum aldosterone with plasma renin activity and the parallel suppression acutely post-PVS, indicate that the level of plasma renin activity is a major determinant of serum aldosterone in refractory ascites. However, the finding of normal preoperative values for plasma renin activity and aldosterone in certain patients, combined with the failure of group B subjects to enter negative sodium balance despite acute normalization of aldosterone, would indicate that factors other than activation of the renin-aldosterone axis contribute to the sodium retention of chronic liver disease. This conclusion is supported by the late results which document persistent sodium retention three months following PVS, despite normalization of aldosterone and presumably normalization of any deficit in effective plasma volume. Can J Gastroenterol 1989;3(3): 103-110 (Pour resumé voir page 104)
\end{abstract}

Key Words: Aldosterone, Ascites, Peritoneovenous shunting, Refractory, Renin

Department of Medicine and Surgery, Toronto General Hospital, University of Toronto,

Toronto, Ontario

Correspondence and reprints: Dr L.M. Blendis, Toronto General Hospital, 200 Elizabeth Street,

Toronto, Ontario M5G 2C4

Received for publication January 3, 1989. Accepted February 6, 1989
T HEROLEOFTHERENIN-ANGIOTENSINaldosterone axis in the sodium retention characteristic of cirrhotics with ascites is still controversial (1). Various methods have been used to study the axis and its relationship to sodium handling in cirrhosis, including correlation of the plasma levels of aldosterone with sodium excretion (2), administration of various antagonists ( 3 ) and different forms of volume manipulation (4).

The introduction by LeVeen (5) of a specifically designed peritoneovenous shunt (PVS) provides, not only a surgical means of relieving massive ascites refractory to medical management, but also affords a unique opportunity to study the acute effects of continuous ascitic fluid reinfusion in cirrhotics. The physiological consequences of both the acute and long term effects of PVS have been well documented $(6,7)$. Acutely, there is a marked volume load, as demonstrated by a fall in hematocrit, without a change in red cell mass (6) and a rise in cardiac output $(6-8)$. There is a rise in effective renal plasma flow (as measured by paraamino hippurate clearance) and creatinine clearance, accompanied by a diuresis and natriuresis $(6,9,10)$. Postoperatively, patients remain clinically free from ascites on either a small dose or no diuretics. However, patients must 


\section{L'axe rénine-aldostérone dans l'ascite hépatique réfractaire: Caractérisation de la réponse de l'axe aux effets à court et à long terme de la dérivation péritonéoveineuse}

RESUME: Vingt-deux patients souffrant d'ascite réfractaire consécutive à une maladie hépatique chronique ont subi une dérivation péritonéoveineuse (PVS). Les sujets ont été étudiés dans les conditions métaboliques rigoureuses d'un régime sodique de $20 \mathrm{mEq}$, avant l'opération et immédiatement après, au cours des premières $8 \mathrm{~h}$. Quatorze sujets ont été réétudiés dans des conditions métabolique similaires trois mois après l'intervention (PVS). Lactivité rénine plasmatique (PRA) et la concentration d'aldostérone sérique étaient toutes deux élevées de façon significative comparées à la normale: PRA $21 \pm 3.7 \mathrm{ng} / \mathrm{mL} / \mathrm{h}$, normale $5,4 \mathrm{ng} / \mathrm{mL} / \mathrm{h}$ ou moins $(\mathrm{P}<0,01)$; aldostérone sérique $2570 \pm 464$ $\mathrm{pg} / \mathrm{mL} / \mathrm{h}$, normale $300 \mathrm{pg} / \mathrm{mL}$ ou moins $(\mathrm{P}<0,01)$. Néanmoins, les valeurs individuelles de ces paramètres s'échelonnaient dans les limites de la normale et la dépassaient pour atteindre des niveaux 20 fois plus élevé. Malgré cette variation, l'aldostérone sérique préopératoire était en corrélation avec la PRA (r $=0,85, \mathrm{n}=22, \mathrm{P}<0,001)$. Treize des 22 patients $(59 \%)$ ont fait une natriurie immédiate grave, et sont entrés en bilan sodique négatif (groupe A), les neuf autres patients $(41 \%)$ n'y sont pas parvenus durant les premières $8 \mathrm{~h}$ postopératoires (groupe B). Avant l'opération, le groupe B se caractérisait par une moyenne préopératoire significativement plus élevée de PRA $36,2 \pm 5,2$ $\mathrm{ng} / \mathrm{mL} / \mathrm{h}$, et d'aldostérone sérique, $4511 \pm 706 \mathrm{pg} / \mathrm{mL}$, comparé au groupe $A$, PRA $9,1 \pm 1,9 \mathrm{ng} / \mathrm{mL} / \mathrm{h}(\mathrm{P}<0,01)$, aldostérone $1232 \pm 198 \mathrm{pg} / \mathrm{mL}(\mathrm{P}<0,01)$. Toutefois, les deux groupes ont subi une charge de volume immédiate équivalente, comme le démontrent les modifications hémodynamiques rénales et systémiques équivalentes. De plus, les niveaux de PRA et d'aldostérone étaient tous deux similaires $8 \mathrm{~h}$ après la dérivation dans les deux groupes. Après trois mois postopératoires, chez les 14 patients réétudiés, la PRA moyenne étaient dans les limites de la normale, $3,0 \pm 0,8 \mathrm{ng} / \mathrm{mL} / \mathrm{h}$ et la concentration moyenne d'aldostêtone sérique n'était pas élevée de façon significative comparée à la normale, $435 \pm 123 \mathrm{pg} / \mathrm{mL}$. Malgré cette normalisation de l'axe réninealdostérone, les patients ont continué à manifester une rétention sodique avec un régime sodique de $20 \mathrm{mEq}$, excrétion sodique moyenne $10,5 \pm 2,8 \mathrm{mEq} / \mathrm{jour}$. La corrélation étroite existant entre l'aldostérone sérique et la PRA, et le freinage parallèle survenu tout de suite après l'intervention chirurgicale (PVS), indique que la niveau de PRA est un déterminant majeur de l'aldostérone sérique dans l'ascite réfractaire. Toutefois, les valeurs préopératoires normales pour la PRA et l'aldostérone chez certains patients, combinées avec le fait que les sujets du groupe $\mathrm{B}$ ne sont pas entrès en bilan sodique positif malgré la normalisation d'aldostérone, semblent indiquer que certains facteurs autres que l'activation de l'axe rénine-aldostérone contribue à la rétention sodique dans la maladie hépatique chronique. Cette conclusion est appuyée par les derniers résultats, qui indiquent une retention sodique persistante trois mois après l'opération (PVS), malgré la normalisation d'aldostérone et la normalisation présumée de tout déficit du volume plasmatique effectif.

continue to limit their sodium intake since when challenged with a high sodium diet they demonstrate sodium retention (7).

Although the effectiveness of PVS insertion is well documented, the mechanism(s) responsible for the partial reversal of salt and water retention remain obscure. The aim of this investigation was to characterize, under strict metabolic conditions, the relationship of changes in plasma renin activity and serum aldosterone to the natriuresis observed post-PVS in a large number of patients with chronic liver disease and refractory ascites.

\section{PATIENTS AND METHODS}

Twenty-two patients with massive ascites refractory to medical management were studied under strict metabolic conditions prior to and for the first $8 \mathrm{~h}$ immediately post-PVS. Ascites was classified as refractory if, on maximum di- uretic therapy in hospital, either no natriuresis was observed or a response occurred at the expense of significant deterioration in either renal function, electrolyte balance and/or development of hepatic encephalopathy. Only patients with stable liver function were considered as suitable candidates; the presence of significant liver dysfunction, ie, prothrombin time prolonged greater than $4 \mathrm{~s}$, bilirubin greater than $65 \mu \mathrm{mol} / \mathrm{L}$ or the presence of hepatic coma, were considered contraindications to PVS. Patients considered suitable candidates were admitted to the clinical investigation unit and placed on a constant 20 $\mathrm{mEq}$ sodium, $80 \mathrm{mEq}$ potassium, $1 \mathrm{~L}$ fluid restricted diet for seven days. All diuretics were stopped prior to entry into the unit.

The clinical details of these 22 patients are presented in Table 1. On each of the final three days in the clinical investigation unit, on the constant diet, the following were obtained: between 07:00 and 08:00, fasting recumbent blood samples for plasma renin activity, serum aldosterone, creatinine and electrolytes; and serial $24 \mathrm{~h}$ collections for urinary electrolytes and creatinine. Plasma and urine creatinine and electrolytes were measured by routine biochemical techniques. Plasma renin activity and serum aldosterone were determined by radioimmunoassay as previously described (6).

On the evening prior to surgery, patients were transferred to the surgical intensive care unit and a Swan-Ganz catheter arterial line and urinary catheter were inserted. The cardiac output was recorded as the mean of three estimations after injection of $5 \%$ dextrose in water by a cardiac output computer (Model 9520; Edwards). The PVS was inserted under general anesthesia as described previously (6).

Postoperatively, the following parameters were studied every $2 \mathrm{~h}$ for a period of $8 \mathrm{~h}$; cardiac output, plasma renin activity, serum aldosterone, hematocrit and plasma creatinine; timed urine collections were obtained for determination of electrolytes and creatinine clearance. During the first $8 \mathrm{~h}$ postoperatively, no subject received diuretics or intravenous blood products. 
TABLE 1

Clinical details of the total series of patients

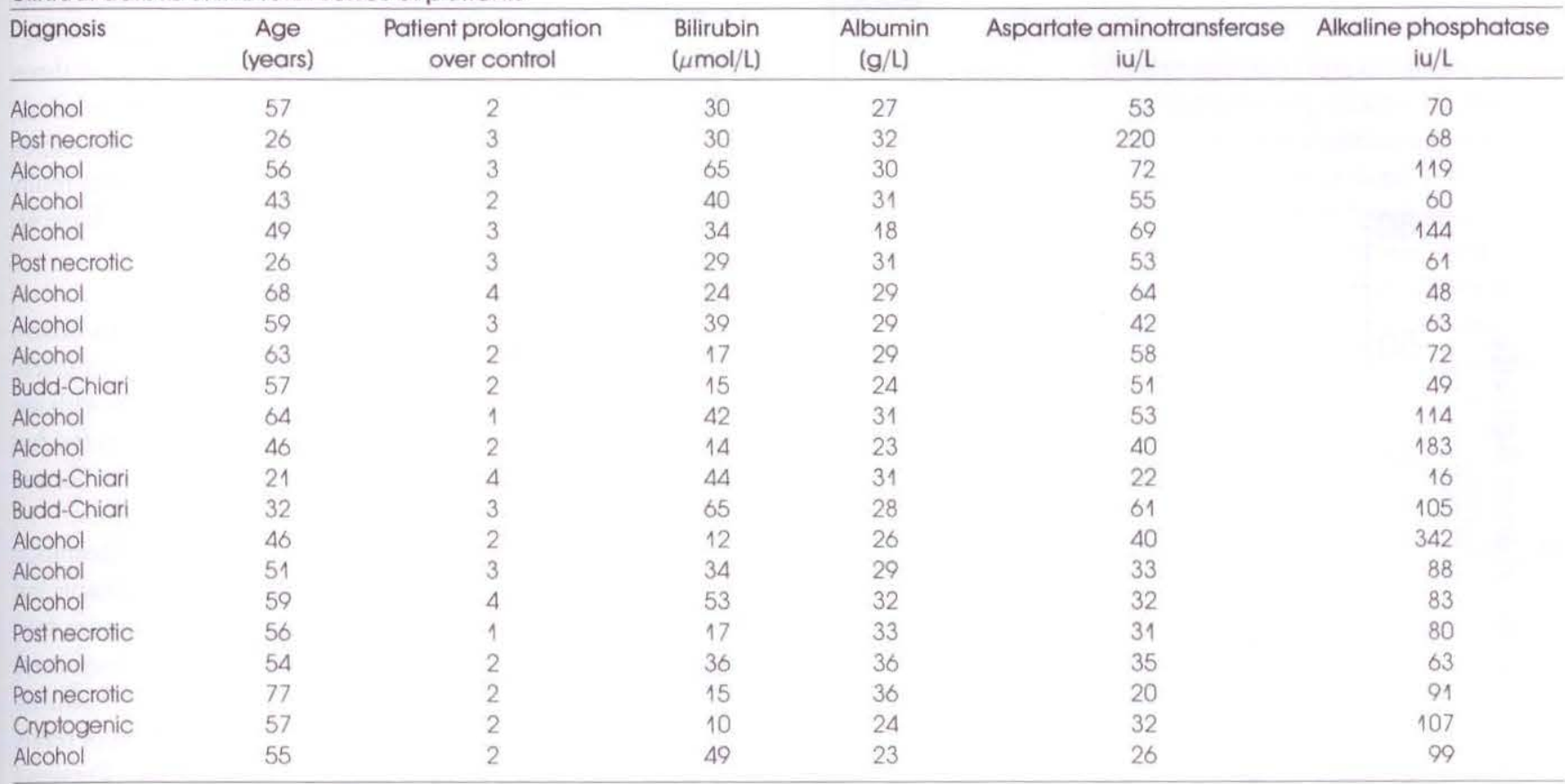

In the first 14 subjects studied using this protocol, effective renal plasma flow was determined pre-and postoperatively by estimation of para-amino hippurate clearance.

Three months following shunt insertion, patients were readmitted to the clinical investigation unit and placed on the same constant $20 \mathrm{mEq}$ sodium diet for seven days. All diuretics were stopped prior to entry into the unit. On each of the final three days in the clinical investigation unit, the following were obtained: fasting recumbent blood samples for plasma renin activity, serum aldosterone, creatinine and electrolytes; and serial $24 \mathrm{~h}$ collections for urinary electrolytes and creatinine.

Approval for performing the metabolic and infusion studies was granted by the University of Toronto Ethics Committee.

The results (unless otherwise stated) represent the mean \pm SD. Statistical significance was determined by paired and unpaired $t$ tests or by two-factor analysis of variance for repeated observations made on the same subject (11). The Newman-Keuls test was used to determine which treatment means were significantly different if the analysis of variance detected a significant effect (12).

\section{RESULTS}

Basal preoperative plasma renin activity and aldosterone: Both mean preoperative plasma renin activity and serum aldosterone levels were markedly elevated, but with large variations (Figure 1). Five individuals had preoperative plasma renin activity values within the normal range and two of these had preoperative aldosterone levels within the normal range. There was no correlation between preoperative urinary sodium excretion and serum aldosterone levels $(\mathrm{r}=0.03, \mathrm{n}=22$, not significant). However, the preoperative serum aldosterone level was directly correlated with plasma renin activity $(\mathrm{r}=0.85, \mathrm{n}=22, \mathrm{P}<0.001)$ and inversely correlated with serum so$\operatorname{dium}(\mathrm{r}=-0.66, \mathrm{n}=22, \mathrm{P}<0.01)$. No correlation was observed between the preoperative serum potassium and serum aldosterone levels $(r=0.24, n=22$, not significant). The preoperative plasma renin activity was inversely correlated with creatinine clearance $(\mathrm{r}=-0.62, \mathrm{n}=22$, $\mathrm{P}<0.01$ ) and para-amino hippurate clearance $(\mathrm{r}=-0.66, \mathrm{n}=14, \mathrm{P}<0.05)$.

Individual natriuretic response to PVS: Although, as a group, the 22 subjects demonstrated a brisk natriuresis, the individual natriuretic response was highly variable (Figure 2 ). The study popu- lation was therefore divided into two groups on the basis of whether or not an individual achieved a negative sodium balance post-PVS, ie, mean sodium excretion greater than $14 \mu \mathrm{Eq} / \mathrm{min}$ (equivalent to ingestion of $20 \mathrm{mEq} /$ day). Group $A$ achieved a negative sodium balance, mean sodium excretion post-PVS greater than or equal to $14 \mu \mathrm{Eq} / \mathrm{min}$; group $\mathrm{B}$ less than $14 \mu \mathrm{Eq} / \mathrm{min}$. Table 2 provides details of the preoperative status of groups A and B. No significant differences were noted in age or in preoperative liver function tests between the two groups. However, mean serum sodium in group $A$ was significantly higher than group $B_{1}(135 \pm 2 \mathrm{mEq} / \mathrm{L}$ versus $126 \pm$ $1 \mathrm{mEq} / \mathrm{L}, \mathrm{P}<0.05)$. Mean preoperative plasma renin activity and serum aldosterone in group A were significantly lower than group $\mathrm{B}(\mathrm{P}<0.01)$ (Figure 3$)$. No difference in mean preoperative cardiac output was noted between the two groups. Mean preoperative para-amino hippurate and creatinine clearances tended to be higher in group $\mathrm{A}$ than group B but mean preoperative urinary sodium excretion and urine volume were equivalent in both groups (Table 2).

Acute effects of PVS in groups A and B: As defined on the basis of the urinary sodium excretion post-PVS, group 


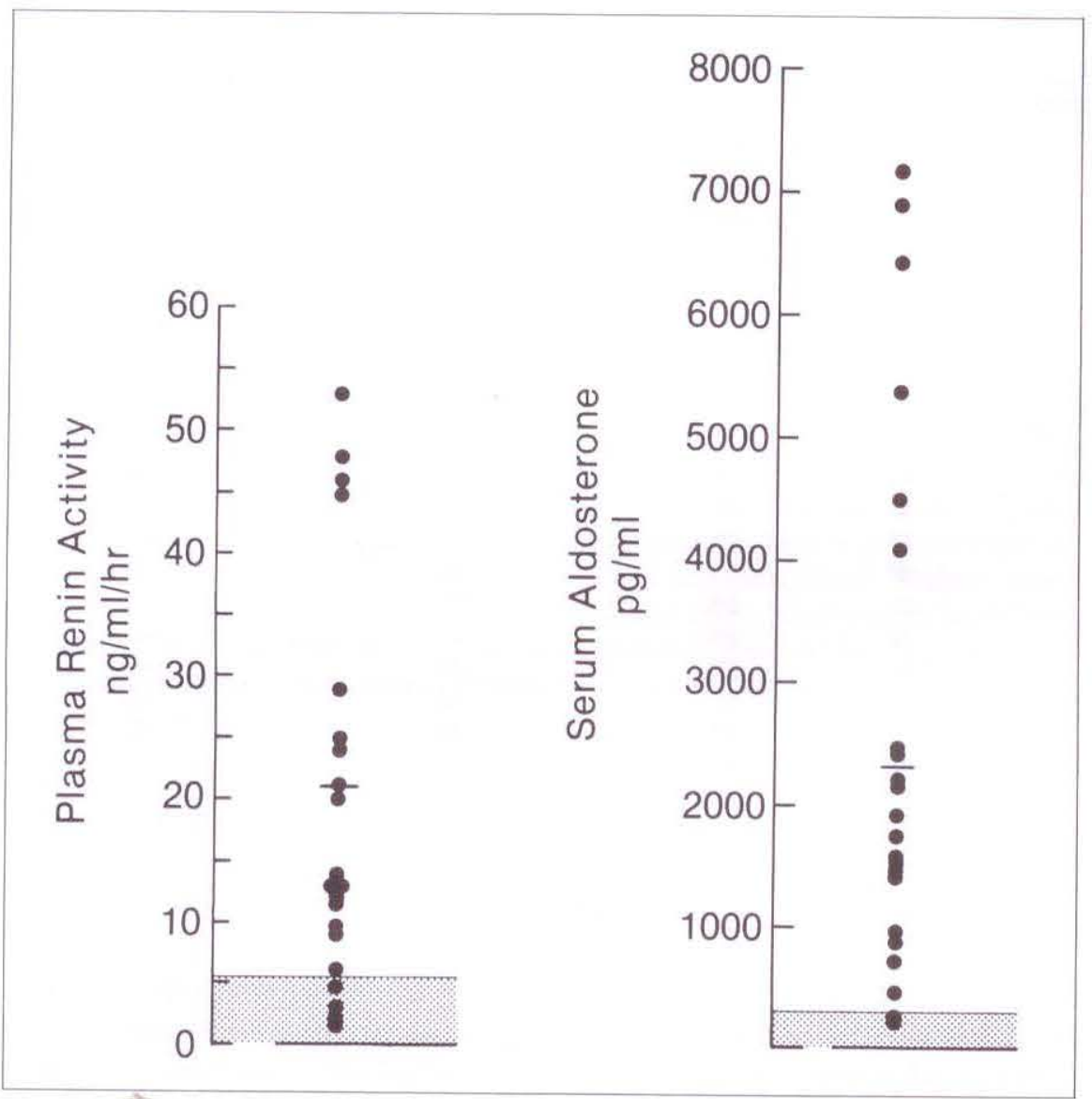

Figure 1) Preoperative individual baseline values in 22 cirrhotics with refractory ascites of plasma renin activity and serum aldosterone. Mean value represented by horizontal bars. Normal range represented by shaded area

A demonstrated a brisk natriuresis, mean sodium excretion increased from $1.8 \pm$ $0.4 \mu \mathrm{Eq} / \mathrm{min}$ to a mean postoperative value of $115 \pm 29.8 \mu \mathrm{Eq} / \mathrm{min}(\mathrm{P}<0.01)$. Group $B$ had a blunted natriuretic response, mean sodium excretion increased from $1.5 \pm 0.4 \mu \mathrm{Eq} / \mathrm{min}$ to a mean postoperative value of $5.2 \pm 1.6 \mu \mathrm{Eq} / \mathrm{min}$ $(\mathrm{P}<0.05)$ (Figure 4a). No differences between the groups were noted in the rise of the urine volume and creatinine clearance (Figure 4a). Following shunt insertion, there were similar increases in cardiac output and para-amino hippurate clearance and an equal fall in hematocrit in both groups (Table 3). In both groups, mean plasma renin activity and mean serum aldosterone fell progressively post-PVS. By $8 \mathrm{~h}$, the mean plasma renin activity and serum aldosterone levels in group B were not significantly different from group $\mathrm{A}$ (Figure $4 \mathrm{~b}$ ).

Three month sodium balance study: Fourteen patients were restudied on a constant $20 \mathrm{mEq}$ sodium diet three months following shunt insertion. Mean sodium excretion on restudy was $7.3 \pm$ $2.1 \mu \mathrm{Eq} / \mathrm{min}(10.5 \pm 2.8 \mathrm{mEq} /$ day $)$, which was significantly higher than the preoperative mean value of $1.9 \pm 0.5$ $\mu \mathrm{Eq} / \min (2.7 \pm 0.7 \mu \mathrm{Eq} /$ day, $\mathrm{P}<0.05)$. Similarly, mean creatinine clearance was $85 \pm 5 \mathrm{~mL} / \mathrm{min}$ which was significantly greater than the preoperative mean value of $65 \pm 4 \mathrm{~mL} / \mathrm{min}(\mathrm{P}<0.05)$.

Mean plasma renin activity was significantly reduced at $3.0 \pm 0.8 \mathrm{ng} / \mathrm{mL} / \mathrm{h}$ compared to a mean preoperative value of $16 \pm 3 \mathrm{ng} / \mathrm{mL} / \mathrm{h}(\mathrm{P}<0.01)$ and was within the normal range for subjects on a $20 \mathrm{mEq}$ sodium diet of 1.2 to $5.4 \mathrm{ng} /$ $\mathrm{mL} / \mathrm{h}$. Mean serum aldosterone was also significantly reduced on restudy at 435 $\pm 123 \mathrm{pg} / \mathrm{mL}$, compared to a mean preoperative value of $2152 \pm 504 \mathrm{pg} / \mathrm{mL}$ $(\mathrm{P}<0.07)$. The urinary sodium excretion correlated with serum aldosterone levels $(r=0.54, n=14, P<0.05)$.
Of the 14 patients that were restudied, nine were from the original group $A$ and five were from group B. No significant differences were noted at three months between these groups in terms of urine volume, urinary sodium excretion, creatinine clearance, plasma renin activity and serum aldosterone (Table 4).

\section{DISCUSSION}

This study confirms previous observations that plasma renin activity levels are usually elevated in subjects with ascites (13-17) but that in some individuals levels may be found within the normal range $(10,13,18)$.

Although decreased hepatic clearance of renin may be partially responsible for the elevation $(18,19)$, the primary factor responsible appears to be increased secretion $(15,16,20)$. The mechanisms responsible for the stimulation of renin release remain controversial. Presumably, stimulation of renin secretion either occurs as a primary event or is secondary to renal hypoperfusion (2). Although some investigators have found an inverse relationship between effective renal plasma flow, creatinine clearance and plasma renin activity $(15,17)$, others have

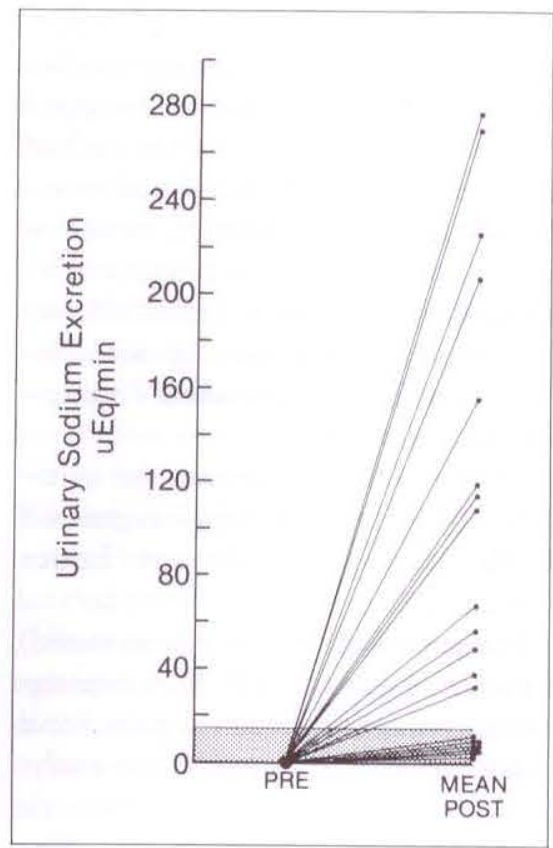

Figure 2) Individual mean rise in sodium excretion from preoperative values during the first $8 \mathrm{~h}$ following shunt insertion. Horizontal line represents a urinary sodium excretion equivalent to $20 \mathrm{mEq} /$ day 


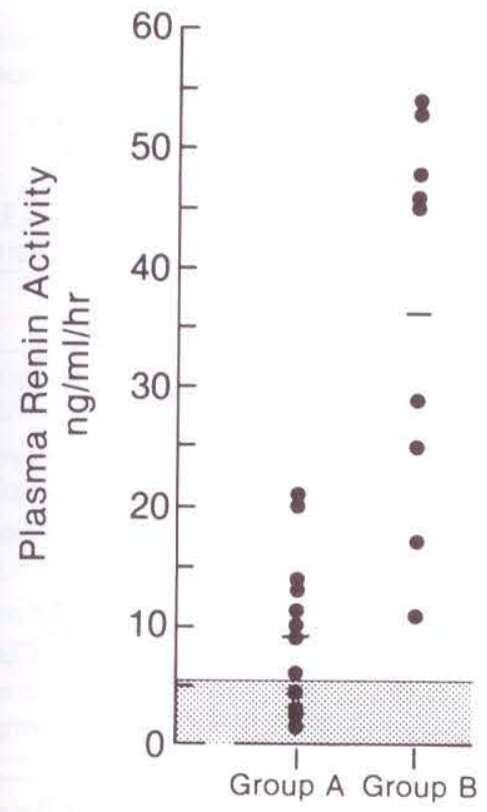

Figure 3) Preoperative individual baseline values of plasma renin activity and serum aldosterone in group A (13 cirrhotics) and group B (nine cirrhotics). Mean values represented by horizontal bar. Normal range represented by shaded area

\section{TABLE 2}

Preoperative status of groups $A$ and $B$

\begin{tabular}{|c|c|c|c|}
\hline & $\begin{array}{l}\text { Group A } \\
(n=13)\end{array}$ & $\begin{array}{c}\text { Group B } \\
(n=9)\end{array}$ & Pvalue \\
\hline Age (years) & $55 \pm 2$ & $44 \pm 6$ & NS \\
\hline Bilirubin $(\mu \mathrm{mol} / \mathrm{L})$ & $31 \pm 4$ & $33 \pm 5$ & NS \\
\hline Albumin (g/L) & $26 \pm 1$ & $27 \pm 1$ & NS \\
\hline Aspartate aminotransferase (iu/L) & $45 \pm 5$ & $64 \pm 20$ & NS \\
\hline Alkaline phosphatase (iu/L) & $103 \pm 21$ & $98 \pm 25$ & NS \\
\hline Patient prolongation over control (s) & $2 \pm 0.1$ & $3 \pm 0.4$ & NS \\
\hline Serum sodium (mEq/L) & $135 \pm 2$ & $126 \pm 1$ & $<0.05$ \\
\hline Hematocrit & $0.36 \pm 0.01$ & $0.35 \pm 0.01$ & NS \\
\hline Plasma renin activity (ng/mL/h) & $9.1 \pm 1.9$ & $36.2 \pm 5.2$ & $<0.01$ \\
\hline Aldosterone $(\mathrm{pg} / \mathrm{mL})$ & $1232 \pm 198$ & $4511 \pm 706$ & $<0.01$ \\
\hline Cardiac output (L/min) & $6.5 \pm 0.5$ & $6.2 \pm 0.5$ & NS \\
\hline \multicolumn{4}{|l|}{ Para-amino hippurate } \\
\hline clearance $(\mathrm{mL} / \mathrm{min})$ & $426 \pm 86$ & $239 \pm 44$ & NS \\
\hline Creatinine clearance $(\mathrm{mL} / \mathrm{min})$ & $65.4 \pm 6.2$ & $47.5 \pm 10.3$ & NS \\
\hline Urinary sodium excretion ( $\mu \mathrm{Eq} / \mathrm{min})$ & $1.8 \pm 0.4$ & $1.5 \pm 0.4$ & NS \\
\hline Urine volume $(\mathrm{mL} / \mathrm{min})$ & $0.45 \pm 0.05$ & $0.42 \pm 0.03$ & NS \\
\hline
\end{tabular}

not been able to confirm this observation (21-23).

In this study a significant negative correlation between preoperative levels of

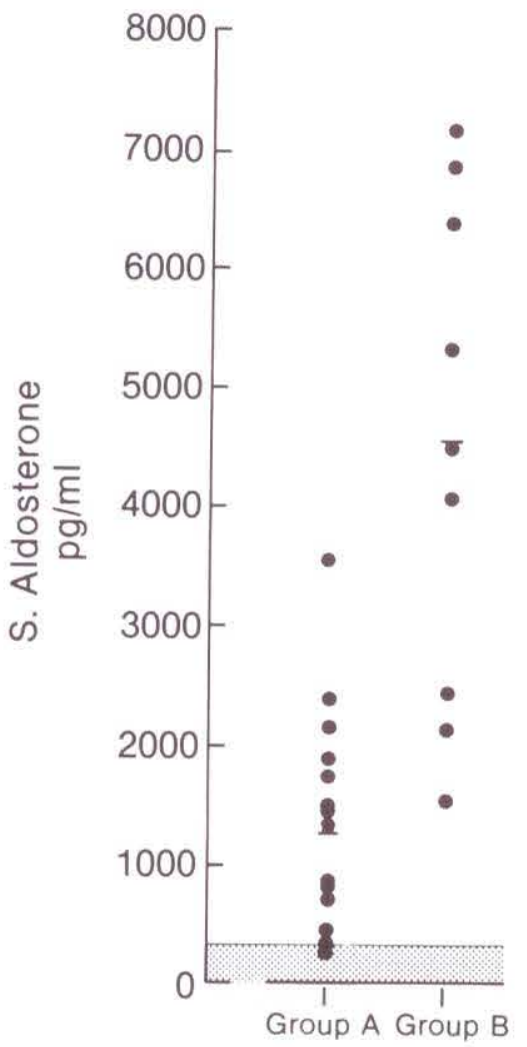

plasma renin activity and both paraamino hippurate and creatinine clearances was found. Although this indicates that a relationship exists between these parameters, such observations provide no information as to whether these variables are directly related (ie, cause and effect) or whether they are all dependent on another primary effector mechanism, eg, increased renal sympathetic tone or intravascular volume depletion.

Serum aldosterone has also previously been documented to be elevated in cirrhotics with ascites and avid sodium retention $(16,17)$ but this is not a universal finding (24). In this study, mean serum aldosterone was markedly elevated, but individual results varied from within the normal range to values 20 -fold greater than the upper limit of normal. Increased secretion is the major determinant of such elevated levels $(16,21)$. This study documented a close relationship between preoperative plasma renin activity and aldosterone, in agreement with previous observations $(21-23,25,26)$ and confirmed an inverse relationship between serum sodium and serum aldosterone levels (24). No correlation was found between serum potassium and serum aldosterone.

Although such static measurements and derived relationships are of interest, they do not clarify the mechanism(s) responsible for the alterations in renin and aldosterone. Much attention and controversy surrounds the intravascular volume status of cirrhotics with ascites (27) and the role of the 'effective plasma volume' $(1,27)$ as a stimulus to sodium retention. It has been suggested that elevations in plasma renin activity and aldosterone, together with elevations in plasma catecholamines and arginine vasopressin are in fact indicators of a reduction in effective plasma volume. Different forms of volume manipulation have been employed in order to study this problem dynamically. One such technique is head out water immersion. Using this technique Epstein et al (26) have documented that, in cirrhotics, plasma renin activity and aldosterone are suppressed by the central hypervolemia induced by head out water immersion in a parallel fashion. This indicated the importance of renin in the control of volume dependent changes in aldosterone in cirrhotics. However, the finding of a disassociation between suppression of aldosterone and a failure of natriuresis in 

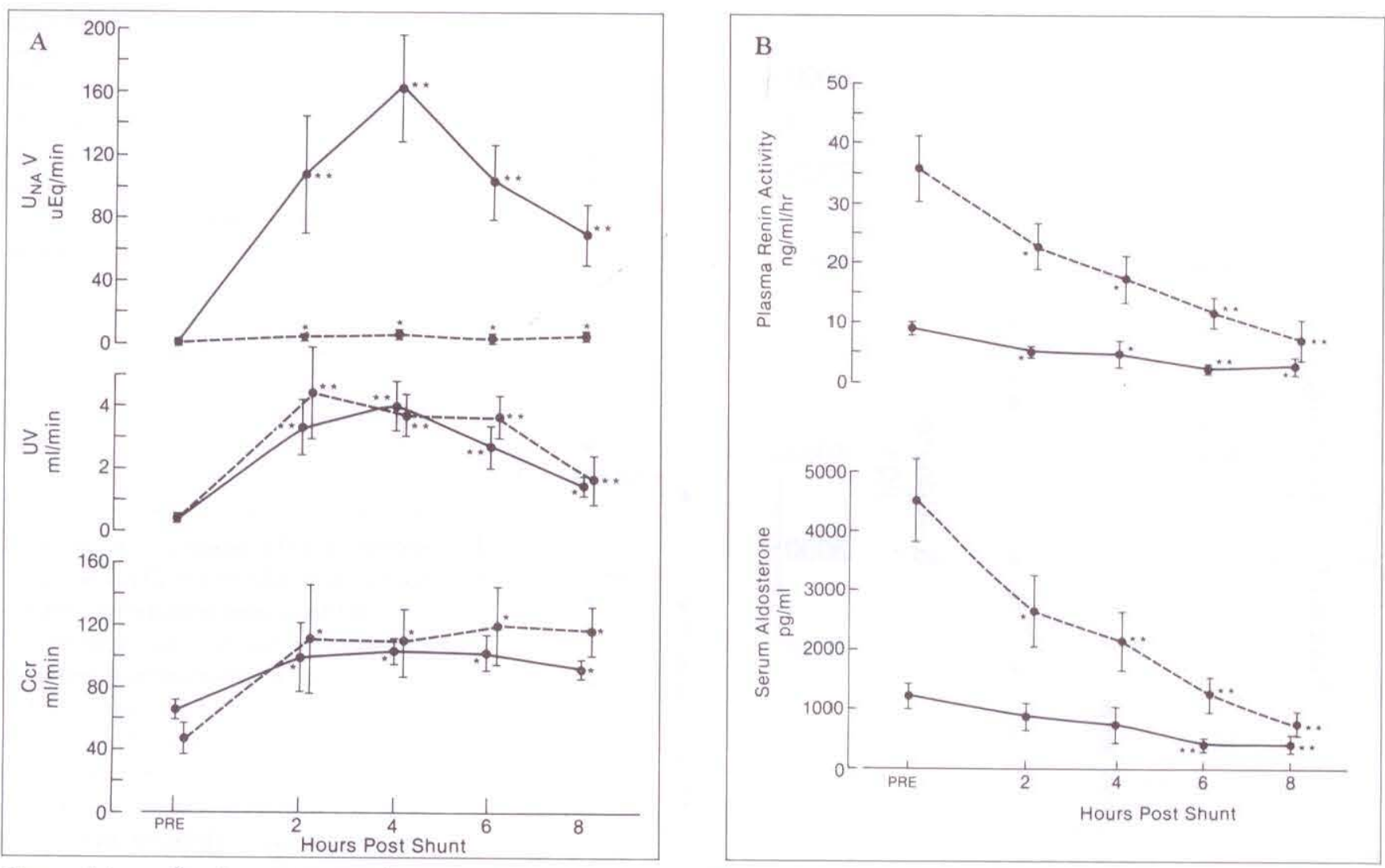

Figure 4) Acute effect of peritoneovenous shunting on $\mathbf{A}$ urine sodium excretion $\left(\mathrm{U}_{\mathrm{NA}} \mathrm{V}\right)$, urine volume (UV) and creatinine clearance (Ccr) and $\mathrm{B}$ plasma renin activity and serum aldosterone in group $\mathrm{A}$ (solid line) and group $\mathrm{B}$ (broken line). ${ }^{*} \mathrm{P}<0.05,{ }^{* *} \mathrm{P}<0.01$, significant values compared to preoperative values

certain patients (26) together with the ability to induce a natriuresis in certain cirrhotics despite large doses of deoxycorticosterone (28), suggests only a permissive role for aldosterone in the sodium retention of cirrhosis. This interpretation has been challenged recently by the finding that head out water immersion, either alone or combined with noradrenaline infusion, in a group of cirrhotics characterized by failure to excrete a water load, only resulted in a natriuresis when plasma aldosterone was suppressed below $50 \mathrm{ng} / \mathrm{dL}(500 \mathrm{pg} / \mathrm{mL})$ (29).

Another model useful in the study of volume manipulation is the acute response to PVS. After shunting there is a rise in cardiac output, with little or no change in arterial blood pressure (6, 8-10) and a fall in hematocrit with no change in red cell mass (6), indicating hemodilution due to an acute volume load. Associated with these changes are increases in effective renal plasma flow and creatinine clearance and a fall in plasma re- nin activity and aldosterone (6).

This study confirms these observations. However, no correlation was found between the rise in sodium excretion from preoperative baseline values and either the fall in aldosterone or the rise in creatinine clearance.

Taken together, the static preoperative observation that there is a close correlation between plasma renin activity and aldosterone, combined with the parallel suppression of plasma renin activity and aldosterone post-PVS, would indicate that the predominant control of aldosterone in cirrhotics is the plasma renin activity angiotensin system and that this axis is responsive to volume changes. This could be viewed as evidence for a decrease in effective plasma volume as a stimulus to the renin-aldosterone system. Furthermore, the separation of the subjects with refractory ascites into two groups based on their natriuretic response allows identification of a subgroup of patients with markedly elevated plasma renin activity and serum aldo- sterone levels and decreased serum sodium, para-amino hippurate and creatinine clearances. These may be indicators of a more advanced degree of effective plasma volume depletion or a different cycle of ascites formation, ie, predominant underfilling.

However, both groups suppressed aldosterone to a comparable level by $8 \mathrm{~h}$ post shunting and had equivalent rises in cardiac output and effective renal plasma flow. The failure of group B patients to achieve a negative sodium balance, despite an equivalent rate of suppression of aldosterone, would indicate that aldosterone has only a permissive role in the sodium retention in chronic liver disease. Group A patients did experience a significant natriuresis and throughout, these patients had a lower mean aldosterone level at each time period (Figure 4). Therefore, it could be proposed that it is not the rate of suppression of aldosterone that is important, but rather the absolute level of aldosterone achieved before a natriuresis is initiated 
TABLE 3

Effects of PVS on cardiac output, hematocrit and para-amino hippurate clearance in groups $A$ and $B$

\begin{tabular}{lcrccc}
\hline & Group & n & Preoperative & Mean postoperative & P \\
\hline Cardiac output & A & 13 & $6.5 \pm 0.5$ & $8.8 \pm 0.7$ & $<0.01$ \\
(L/min) & B & 9 & $6.0 \pm 0.5$ & $8.7 \pm 0.7$ & $<0.01$ \\
Hematocrit & A & 13 & $0.36 \pm 0.01$ & $0.28 \pm 0.02$ & $<0.05$ \\
& B & 9 & $0.35 \pm 0.01$ & $0.26 \pm 0.01$ & $<0.05$ \\
Para-amino hippurate & A & 7 & $426 \pm 85$ & $692 \pm 156$ & $<0.05$ \\
clearance (mL/min) & B & 7 & $239 \pm 43$ & $520 \pm 86$ & $<0.05$ \\
\hline
\end{tabular}

TABLE 4

Late results: Three months post-PVS

\begin{tabular}{llccc}
\hline & \multicolumn{1}{c}{$\begin{array}{c}\text { Group A } \\
(n=9)\end{array}$} & $\begin{array}{c}\text { Group B } \\
(n=5)\end{array}$ & Pvalue \\
\hline Urine volume & Preoperative & $0.51 \pm 0.1$ & $0.47 \pm 0.04$ & NS \\
(mL/min) & Late postoperative & $0.6 \pm 0.1$ & $0.66 \pm 0.07$ & NS \\
Urinary sodium excretion & Preoperative & $2.1 \pm 0.5$ & $1.4 \pm 0.6$ & NS \\
( $\mu$ Ea/min) & Late postoperative & $8.2 \pm 2.8$ & $5.8 \pm 2.9$ & NS \\
Creatinine clearance & Preoperative & $6.5 \pm 5$ & $53 \pm 4$ & NS \\
(mL/min) & Late postoperative & $79 \pm 5$ & $96 \pm 6$ & NS \\
Plasma renin activity & Preoperative & $8.9 \pm 2.1$ & $27 \pm 5.3$ & $<0.01$ \\
(ng/mL/h) & Late postoperative & $2.6 \pm 0.8$ & $4.6 \pm 1.8$ & NS \\
Serum aldosterone & Preoperative & $1181 \pm 272$ & $3898 \pm 726$ & $<0.01$ \\
(pg/mL) & Late postoperative & $363 \pm 113$ & $564 \pm 290$ & NS \\
\hline
\end{tabular}

(28). Against this proposal is the observation that the natriuresis in group $\mathrm{A}$ was immediate and peaked at $4 \mathrm{~h}$ whereas absolute values for aldosterone fell slowly and progressively in the group and

ACKNOWLEDGEMENTS: Dr P.J. Campbell was a fellow of the Medical Research Council of Canada.

\section{REFERENCES}

1. Epstein M. Pathogenesis of renal sodium handling in cirrhosis. A re-appraisal. Am J Nephrol 1983;3:297-309.

2. Epstein $\mathrm{M}$. The renin-angiotensin system in liver disease. In: Epstein M, ed. Kidney in Liver Disease, 2nd edn. New York: Elsevier, 1983:353-75.

3. Hollenberg NK. Renin angiotensin and the kidney: Assessment by pharmacologic interruption of the reninangiotensin system. In: Epstein M, ed. Kidney in Liver Disease, 2nd edn. New York: Elsevier, 1983:395-411.

4. Epstein M, Sancho J, Haber E. Renin-aldosterone responsiveness in decompensated cirrhosis. In: Epstein M, ed. Kidney in Liver Disease, 2nd edn. New York: Elsevier, 1983:413-22. did not fall below $500 \mathrm{pg} / \mathrm{mL}$ ( $50 \mathrm{ng} / \mathrm{dL}$ ), until $6 \mathrm{~h}$ post shunting.

The late results demonstrate that, despite normalization of plasma renin activity and therefore presumably restor-

5. LeVeen $\mathrm{HH}$, Christoudias G.

Peritoneovenous shunting for ascites.

Ann Surg 1974;180:580-91.

6. Blendis LM, Greig PD, Langer B, Baigre RS, Ruse J, Taylor BR. The renal and haemodynamic effects of the peritoneovenous shunt for intractable ascites. Gastroenterology 1979:77:250-7.

7. Greig PD, Blendis LM, Langer B, Taylor BR, Colapinto RF. Renal and haemodynamic effects of the peritoneovenous shunt, II. Long term effects.

Gastroenterology 1981;80:119-25.

8. Samanta A, Nakem A. Thakkar V, Kiernan T, Leevy CM. Influence of peritoneo-jugular (PJ) shunt on hepatic and cardiopulmonary haemodynamics. Gastroenterology 1978;75:986A. (Abst)

9. Greig PD, Blendis LM, Langer B, Ruse J, Taylor BR. The acute effects of sustained volume expansion on the renin aldosterone system and renal function in human hepatic ascites. J Lab Clin Med 1981;98:127-34.

10. Reznick RK, Langer B, Taylor BR, Seif S, ation of 'effective' intravascular volume, as a group the patients were still in positive sodium balance. The late results combined with the acute results would, therefore, suggest that simple restoration of effective intravascular volume and suppression of the renin aldosterone axis is insufficient to fully correct the sodium retention present in cirrhotics.

In conclusion, this study has documented that levels of plasma renin activity and aldosterone are usually elevated in refractory ascites. The close correlation documented between preoperative plasma renin activity and aldosterone and the parallel fall of these parameters post-PVS, suggests that the major determinant in controlling aldosterone is the level of plasma renin activity. However, if the elevated levels of these parameters are indeed a reflection of a reduction in effective plasma volume, then patients with refractory ascites represent a heterogeneous population. Furthermore, the finding that those patients with most marked elevation in plasma renin activity and aldosterone fail to enter negative sodium balance, despite an equal reinfusion of ascitic fluid, indicates that aldosterone, which is equally suppressed in this group, is not the major determinant of sodium retention in cirrhotics with refractory ascites.

Blendis LM. Hyponatraemia and arginine vasopressin secretion in patients with refractory hepatic ascites undergoing peritoneovenous shunting. Gastroenterology 1983;84:713-8.

11. Edwards AL. Multiple Regression and the Analysis of Variance and Co-variance. New York: WH Freenand and Company, 1979.

12. Snedecor GW, Cochran WG. Statistical Methods, 7th edn. Ames, lowa: Iowa State University Press, 1980.

13. Wilkinson SP, Smith IK, Williams R. Changes in plasma renin activity in cirrhosis: A re-appraisal on studies in 67 patients and "low renin" cirrhosis. Hypertension 1979;1:125-9.

14. Schroeder ET, Eich RH, Smulyan $\mathrm{H}$, Gould AB, Gabuzda G]. Plasma renin level in hepatic cirrhosis: Relation to functional renal failure. Am J Med 1970;15:419-25.

15. Kondo K, Nakamura R, Saito I, Saruta T, Matsuki S. Renin, angiotensin Il and juxtaglomerular apparatus in liver cirrhosis. Jpn Circ J 1974:38:913-21. 
16. Rossoff L Jr, Zia P, Reynolds T, Horton R. Studies of renin and aldosterone in cirrhotic patients with ascites. Gastroenterology 1975;69:698-705.

17. Barnado DE, Summerskill WHJ, Strong CG, Baldus WP. Renal function, renin activity and endogenous vaso-active substance in cirrhosis. Am J Dig Dis 1970;15:419-25.

18. Barnado DE, Strong CG, Baldus WP. Failure of cirrhotic liver to inactivate renin. Evidence for a splanchnic source of renin like activity. J Lab Clin Med 1969;74:495-506.

19. Heacox R, Harvey AM, Vander AJ. Hepatic inactivation of renin. Circ Res 1967;21:149-52.

20. Hesse B, Andersen ED, Ring-Larsen H. Hepatic elimination of renin in man. Clin Sci Mol Med 1978;55:377-82.
21. Arroyo V, Bosch J, Mauri M, et al. Renin, aldosterone and renal haemodynamics in cirrhosis with ascites. Eur ] Clin Invest 1979;9:69-73.

22. Bosch J, Arroyo V, Betriu A, et al. Hepatic haemodynamics and the renin-angiotensin-aldosterone system in cirrhosis. Gastroenterology 1980;78:92-9.

23. Chonko AM, Bay WH, Stein JH, Ferris TF. The role of renin and aldosterone in the salt retention of edema. Am J Med 1977;63:881-9.

24. Epstein M. Aldosterone in liver disease. In:Epstein M, ed. Kidney in Liver Disease, 2 nd edn. New York: Elsevier, 1983:377-99.

25. Mitch WE, Whelton PK, Cooke CR, Walker WG, Maddrey WC. Plasma levels and hepatic extraction of renin and aldosterone in alcoholic liver disease. Am J Med 1979;66:804-10

26. Epstein M, Levinson R, Sancho J, Haber E, Re R. Characterization of the renin-aldosterone system in decompensated cirrhosis. Circ Res 1977;41:818-29.

27. Better OS, Schrier RW. Disturbed volume homeostasis in patients with cirrhosis of the liver. Kidney Int 1983;23:303-11.

28. Epstein M, Pins DS, Schneider N, Levinson R. Determinants of deranged sodium and water homeostasis in decompensated cirrhosis. J Lab Clin Med 1976;87:822-39.

29. Nicholls KM, Shapiro MD, Kluge R, Chung HM, Bichet DG, Schrier RW. Sodium excretion in advanced cirrhosis: Effect of expansion of central blood volume and suppression of plasma aldosterone. Hepatology 1986;6:235-8. 


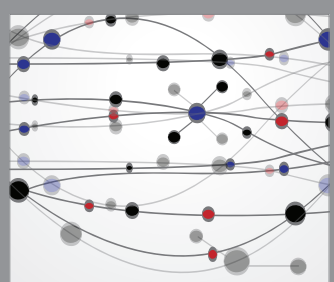

The Scientific World Journal
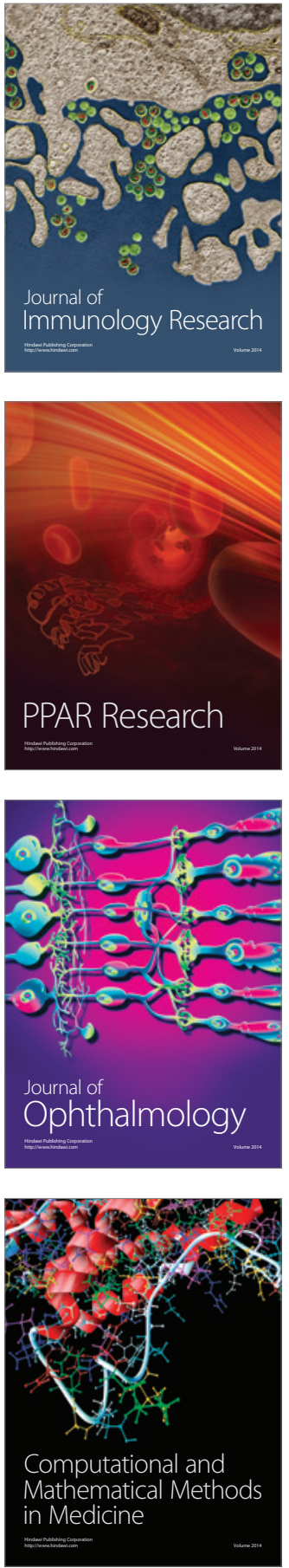

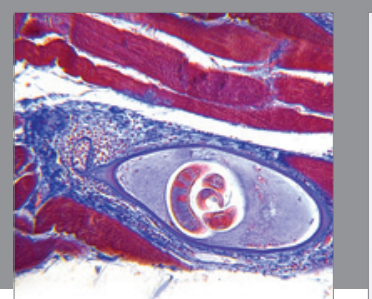

Gastroenterology Research and Practice

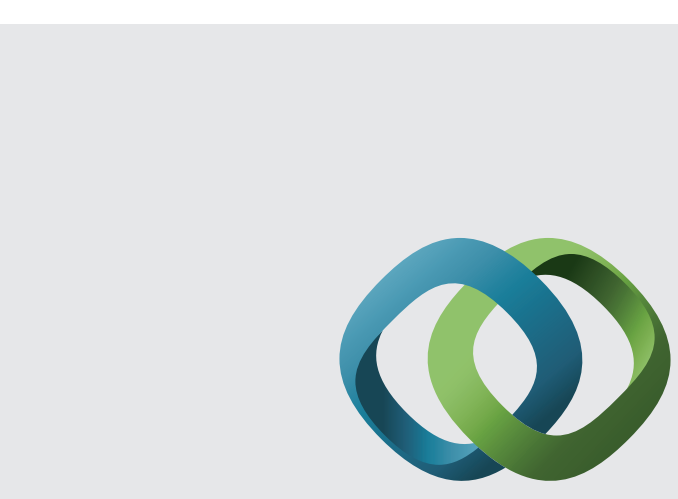

\section{Hindawi}

Submit your manuscripts at

http://www.hindawi.com
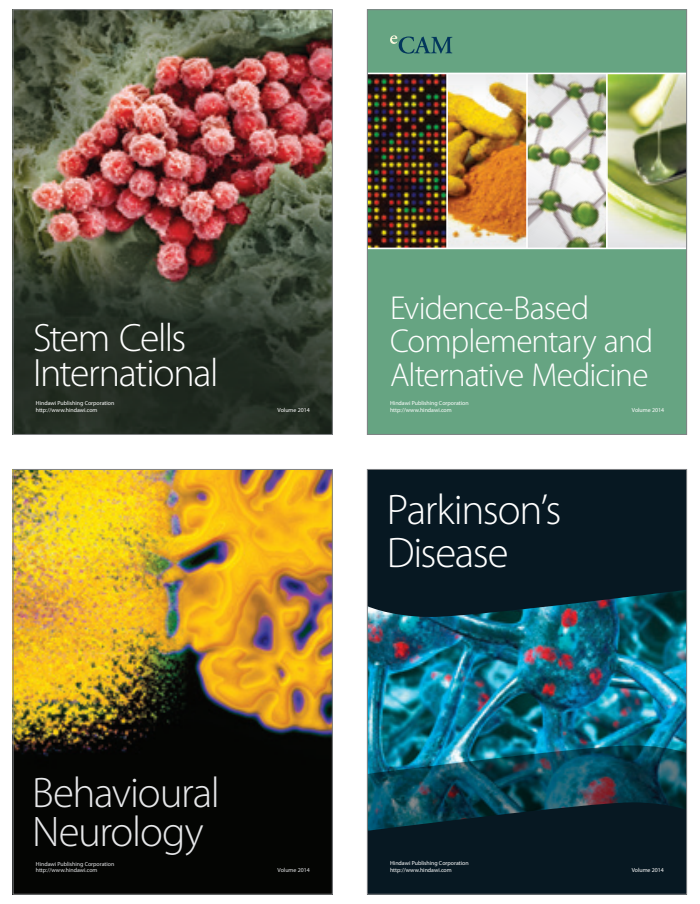
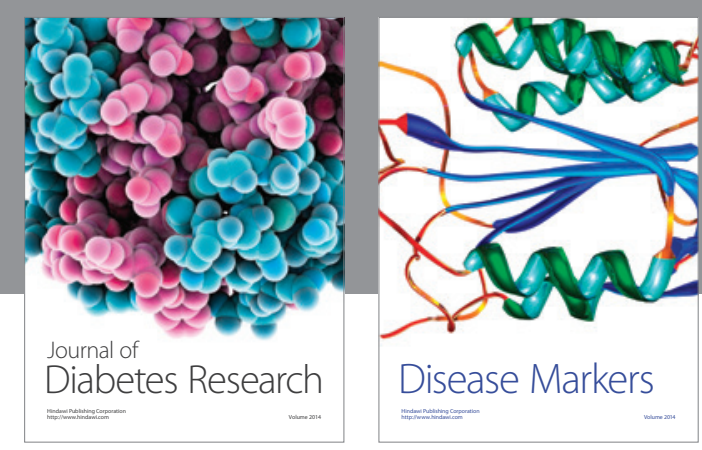

Disease Markers
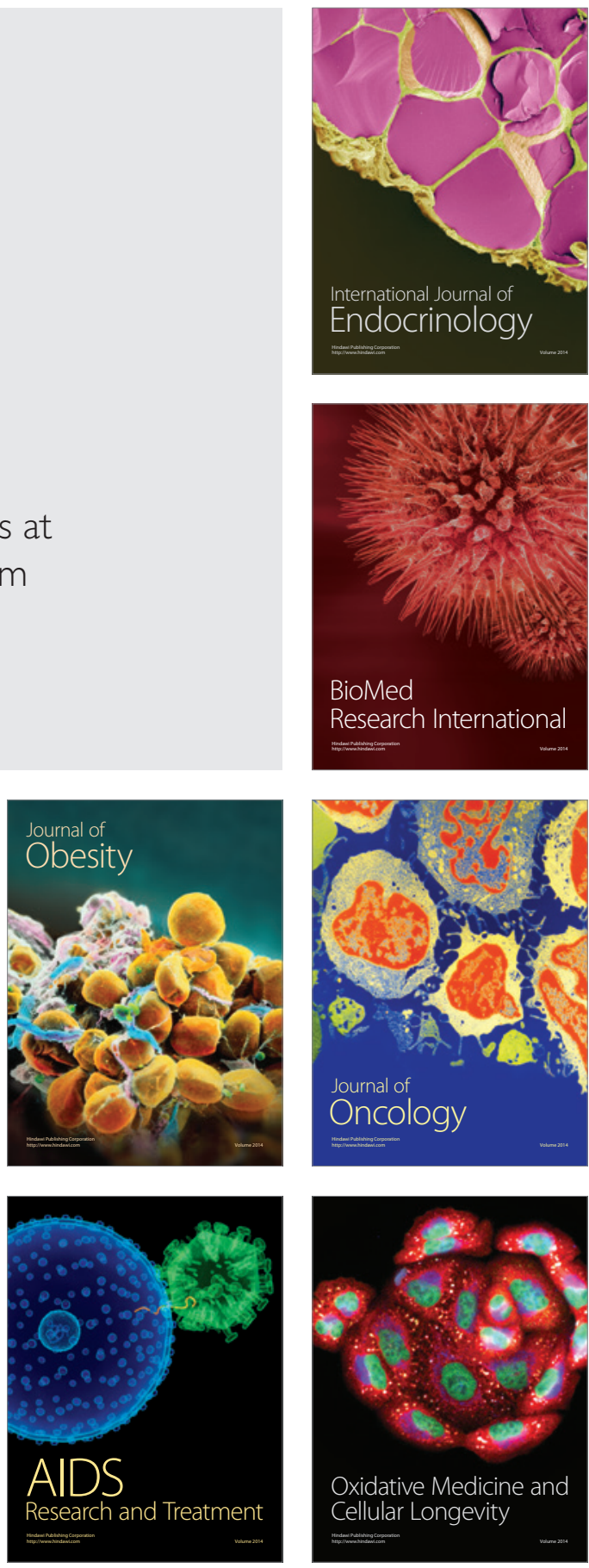